\title{
1-Phenyl-3-(quinolin-5-yl)urea as a host for distinction of phthalic acid and terephthalic acid
}

\author{
DIPJYOTI KALITA and JUBARAJ B BARUAH* \\ Department of Chemistry, Indian Institute of Technology Guwahati, North Guwahati 781 039, India \\ e-mail: juba@iitg.ernet.in
}

MS received 21 January 2012; revised 26 July 2012; accepted 2 August 2012

\begin{abstract}
Co-crystals of 1-phenyl-3-(quinolin-5-yl)urea (1) with terephthalic acid, adipic acid; and salts of 1 with phthalic acid, $p$-toluenesulphonic acids are prepared and structurally characterized. The reaction of phthalic acid and $p$-toluenesulphonic acid resulted in protonation of the host $\mathbf{1}$, whereas the terephthalic acid and adipic acid interact with $\mathbf{1}$, led to cocrystals with the host $\mathbf{1}$ through hydrogen bond interactions. The hydrogen bonds that appears in the urea taps of the host molecules $\mathbf{1}$ are lost while formation of salts; in such cases anions interacts with the urea portion of the host, while in the co-crystals the hydrogen bonded urea taps are retained. The salts are yellow in colour while the co-crystals are colourless; thereby the positional isomer phthalic acid can be distinguished from the terephthalic acid.
\end{abstract}

Keywords. 1-Phenyl-3-(quinolin-5-yl)urea; hydrogen bond; co-crystal; salt; visual distinction.

\section{Introduction}

The anion recognition property of urea derivatives are well-known in both in solid and in solution state. ${ }^{1-5}$ Hosts having urea motif are useful for selective binding of carboxylic acids such as dibutylmalonic acid. ${ }^{6}$ Owing to their versatile biological applications, design and synthesis of hosts for selective binding of carboxylic acids have gained interest in recent time. ${ }^{7-12}$ There are several examples of hosts for dicarboxylic acids and their binding properties are explored in details. ${ }^{13-22}$ Troger's base analogues have been reported to recognize dicarboxylic acids with different chain lengths. ${ }^{23-28}$ Recently, it is shown that dicarboxylic acids form salts and co-crystals with pyridine hosts depending on the orientation of the acid groups. ${ }^{29-35}$ Further to this conformational change in dicarboxylic acid by hosts have practical applications in memory devices. ${ }^{36,37}$ Binding of the carboxylic acids to nitrogen containing hosts have great diversity ${ }^{37,38}$ and upon such binding also leads to changes in the physical properties from the parent compounds. ${ }^{38}$ We have shown that urea derivative 1-phenyl-3-(quinolin-5-yl)urea (1) is a good host in recognizing the cis and trans unsaturated acids. ${ }^{39}$ In this report, we discuss structural features of salt and cocrystals of $\mathbf{1}$ with rigid and flexible carboxylic acids (scheme 1) and about visual distinction

*For correspondence of two positional isomers phthalic acid and terephthalic acid by this host.

\section{Experimental}

\subsection{Synthesis of 1-phenyl-3-(quinolin-5-yl)urea (1)}

5-Aminoquinoline $(0.721 \mathrm{~g}, 5 \mathrm{mmol})$ was dissolved in dry dichloromethane $(10 \mathrm{~mL})$ and to this solution another solution of phenylisocyanate $(0.54 \mathrm{~mL}$, $5 \mathrm{mmol}$ ) in dichloromethane was added drop-wise and the mixture was stirred at room temperature for $3 \mathrm{~h}$. The product formed was filtered and recrystallized from methanol. Yield: 78\%. IR (KBr, cm $\left.{ }^{-1}\right): 3280$ (s), 3062 (m), 1641 (s), 1599 (s), 1557 (s), 1493 (s), 1449 (m), 1315 (m), 1249 (s), 1091 (w), 799 (m), 748 (m), 694 (m). ${ }^{1} \mathrm{HNMR}$ (DMSO- $\left.d_{6}, 400 \mathrm{MHz}, \mathrm{ppm}\right): 8.8(3 \mathrm{H}, \mathrm{m})$, $8.4(1 \mathrm{H}, \mathrm{d}, \mathrm{J}=8.8 \mathrm{~Hz}), 8.0(1 \mathrm{H}, \mathrm{d}, \mathrm{J}=7.2 \mathrm{~Hz}), 7.6(2 \mathrm{H}$, m), $7.4(3 \mathrm{H}, \mathrm{m}), 7.2(2 \mathrm{H}, \mathrm{m}), 7.0(1 \mathrm{H}, \mathrm{t}, \mathrm{J}=7.2 \mathrm{~Hz}) .{ }^{13} \mathrm{C}$ NMR(DMSO- $\left.d_{6}, 100 \mathrm{MHz}, \mathrm{ppm}\right): 118.3,118.9,121.4$, $121.9,122.7,124.5,129.5,130.1,130.8,135.4,140.2$, 148.8, 150.9, 153.5. LC-MS [M + 1]: 264.13.

\subsection{Synthesis of the salts and co-crystals of 1}

The compound $\mathbf{1}$ and the dicarboxylic acids (1:1) were dissolved in aqueous methanol. Slow evaporation of the solution results in colourless crystals of the co-crystals whereas in case of salts yellow coloured crystals were observed. 

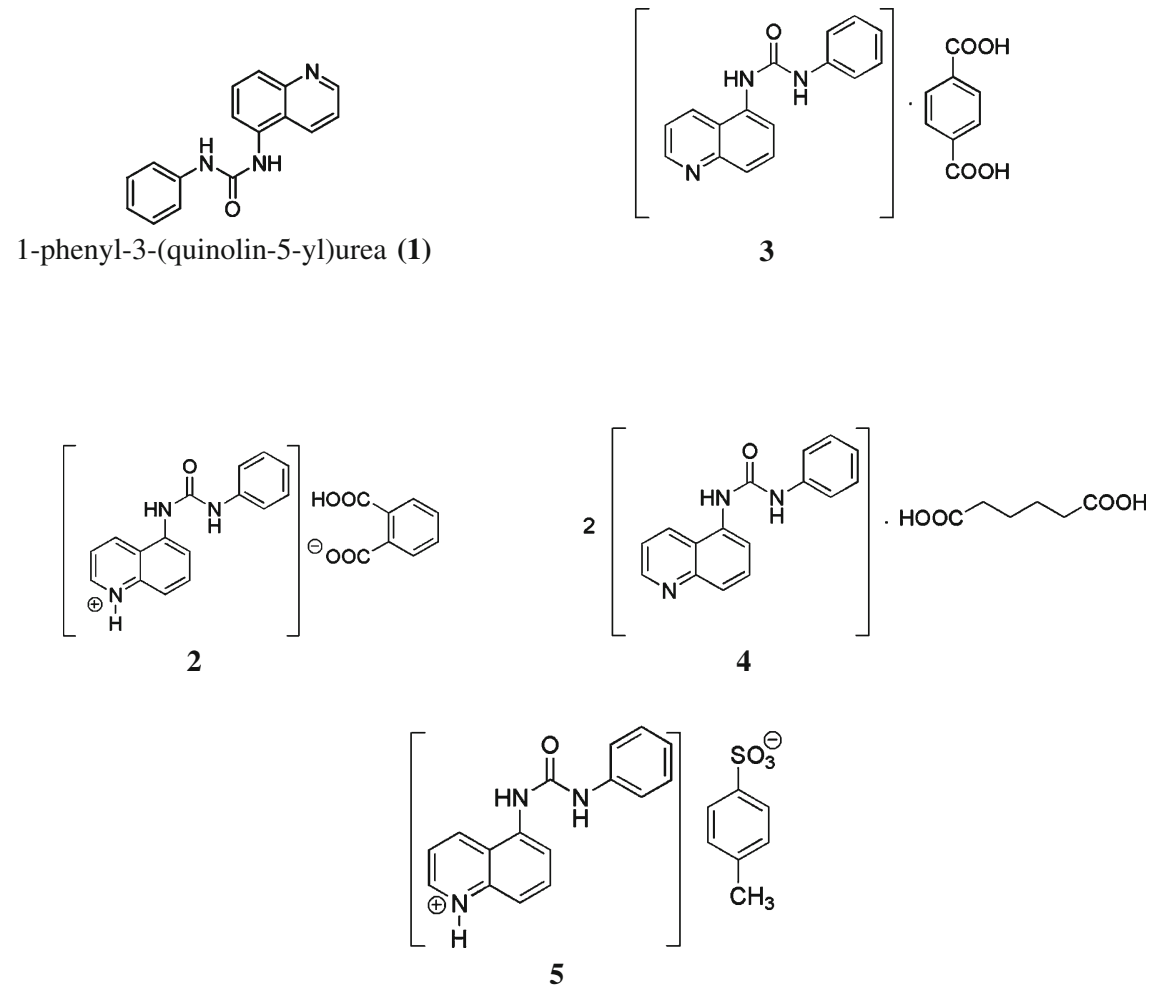

Scheme 1. The host and its salts and cocrystals.

2.2a Salt of 1 with phthalic acid: Isolated Yield: 69\%. IR (KBr, cm $\left.{ }^{-1}\right): 3444$ (w), 2924 (w), 1695 (s), 1587 (m), 1535 (m), $1406(\mathrm{~m}), 1284(\mathrm{~s}), 1072(\mathrm{~m})$, 737 (m). ${ }^{1} \mathrm{HNMR}$ (DMSO- $\left.d_{6}, 400 \mathrm{MHz}, \mathrm{ppm}\right): 9.0(1 \mathrm{H}$, s), $8.9(2 \mathrm{H}, \mathrm{m}), 8.5(1 \mathrm{H}, \mathrm{d}, \mathrm{J}=7.6 \mathrm{~Hz}), 8.0(2 \mathrm{H}, \mathrm{m})$, $7.6(5 \mathrm{H}, \mathrm{m}), 7.5(3 \mathrm{H}, \mathrm{m}), 7.3(2 \mathrm{H}, \mathrm{d}, \mathrm{J}=7.6 \mathrm{~Hz}), 7.0$ $(1 \mathrm{H}, \mathrm{d}, \mathrm{J}=6.8 \mathrm{~Hz}) . \mathrm{UV}$-vis \{methanol, $\mathrm{nm}(\varepsilon)\} 320(1.3$ $\left.\times 10^{4} \mathrm{~cm}^{-1} \mathrm{~mol}^{-1}\right) ; 400\left(6 \times 10^{3} \mathrm{~cm}^{-1} \mathrm{~mol}^{-1}\right)$.

2.2b Co-crystal of 1 with terephthalic acid: Isolated Yield: 67\%. IR $\left(\mathrm{KBr}, \mathrm{cm}^{-1}\right): 3444$ (w), 3266 (s), 2925(w), 1698 (s), 1637 (s), 1599 (s), 1562 (s), 1496 (m), 1275 (s), 1253 (m), 807 (m), 729 (m). ${ }^{1}$ HNMR (DMSO- $\left.d_{6}, 400 \mathrm{MHz}, \mathrm{ppm}\right): 9.0(1 \mathrm{H}, \mathrm{s}), 8.9(2 \mathrm{H}, \mathrm{m})$, $8.5(1 \mathrm{H}, \mathrm{d}, \mathrm{J}=8.8 \mathrm{~Hz}), 8.0(5 \mathrm{H}, \mathrm{m}), 7.7(2 \mathrm{H}, \mathrm{m}), 7.6$ $(1 \mathrm{H}, \mathrm{m}), 7.5(2 \mathrm{H}, \mathrm{d}, \mathrm{J}=7.6 \mathrm{~Hz}), 7.3(2 \mathrm{H}, \mathrm{t}, \mathrm{J}=7.2 \mathrm{~Hz})$, $7.0(1 \mathrm{H}, \mathrm{t}, \mathrm{J}=7.2 \mathrm{~Hz})$. UV-vis \{methanol, $\mathrm{nm}(\varepsilon)\} 320$ $\left(1.6 \times 10^{4} \mathrm{~cm}^{-1} \mathrm{~mol}^{-1}\right)$.

2.2c Co-crystal of 1 with adipic acid: $\quad$ Isolated Yield: 74\%. IR (KBr, cm ${ }^{-1}$ ): 3436 (w), 3270 (s), 2945 (w), 1716 (s), 1639 (s), 1598 (s), 1561 (s), 1496 (m), 1258 (m), $1173(\mathrm{~m}), 805$ (m). ${ }^{1} \mathrm{HNMR}$ (DMSO- $d_{6}, 400 \mathrm{MHz}$, ppm): $9.0(1 \mathrm{H}, \mathrm{s}), 8.9(2 \mathrm{H}, \mathrm{m}), 8.5(1 \mathrm{H}, \mathrm{d}, \mathrm{J}=8.4 \mathrm{~Hz})$, $8.0(1 \mathrm{H}, \mathrm{d}, \mathrm{J}=6.8 \mathrm{~Hz}), 7.7(2 \mathrm{H}, \mathrm{m}), 7.6(1 \mathrm{H}, \mathrm{m}), 7.5$ $(2 \mathrm{H}, \mathrm{d}, \mathrm{J}=8.0 \mathrm{~Hz}), 7.3(2 \mathrm{H}, \mathrm{t}, \mathrm{J}=8.0 \mathrm{~Hz}), 7.0(1 \mathrm{H}, \mathrm{t}$, $\mathrm{J}=7.2 \mathrm{~Hz}), 2.2(2 \mathrm{H}, \mathrm{m}), 1.5(2 \mathrm{H}, \mathrm{m})$.
$2.2 \mathrm{~d} \quad p$-Tolunesulphonate salt of 1: The compound 1 and $p$-tolunesulphonic acids (1:1) were dissolved in aqueous methanol. Slow evaporation of the solution results in yellow coloured crystals of salt $\mathbf{5}$. Isolated yield: 64\%. IR (KBr, cm $\left.{ }^{-1}\right)$ : 3291 (w), 2922 (w), 1708 (s), 1637 (m), 1600 (m), 1539 (s), 1417 (m), 1366 (m), 1212 (s), 1165 (m), 1126 (m), 1033 (m), 1009 (m), 795 (m). ${ }^{1} \mathrm{HNMR}$ (DMSO- $\left.d_{6}, 400 \mathrm{MHz}, \mathrm{ppm}\right): 9.4(1 \mathrm{H}, \mathrm{s})$, $9.2(2 \mathrm{H}, \mathrm{m}), 8.2(1 \mathrm{H}, \mathrm{d}, \mathrm{J}=7.6 \mathrm{~Hz}), 8.0(2 \mathrm{H}, \mathrm{m}), 7.8$ $(1 \mathrm{H}, \mathrm{d}, \mathrm{J}=8.0 \mathrm{~Hz}), 7.5(5 \mathrm{H}, \mathrm{m}), 7.3(2 \mathrm{H}, \mathrm{m}), 7.1(2 \mathrm{H}$, $\mathrm{d}, \mathrm{J}=7.6 \mathrm{~Hz}), 7.0(1 \mathrm{H}, \mathrm{t}, \mathrm{J}=7.2 \mathrm{~Hz}), 2.2(3 \mathrm{H}, \mathrm{s})$.

\section{$2.3 X$-ray crystallographic studies}

Diffraction data for compounds were collected at $296 \mathrm{~K}$ with Mo K $\alpha$ radiation $(\lambda=0.71073 \AA)$ using a Bruker Nonius SMART APEX CCD diffractometer equipped with graphite monochromator and Apex CD camera. The SMART software was used for data collection and also for indexing the reflections and determining the unit cell parameters. Data reduction and cell refinement were performed using SAINT software and the space groups of these crystals were determined from systematic absences by XPREP and further justified by the refinement results. The structures were solved by direct methods and refined by full-matrix least-square calculations using SHELXTL software. All the non-H 


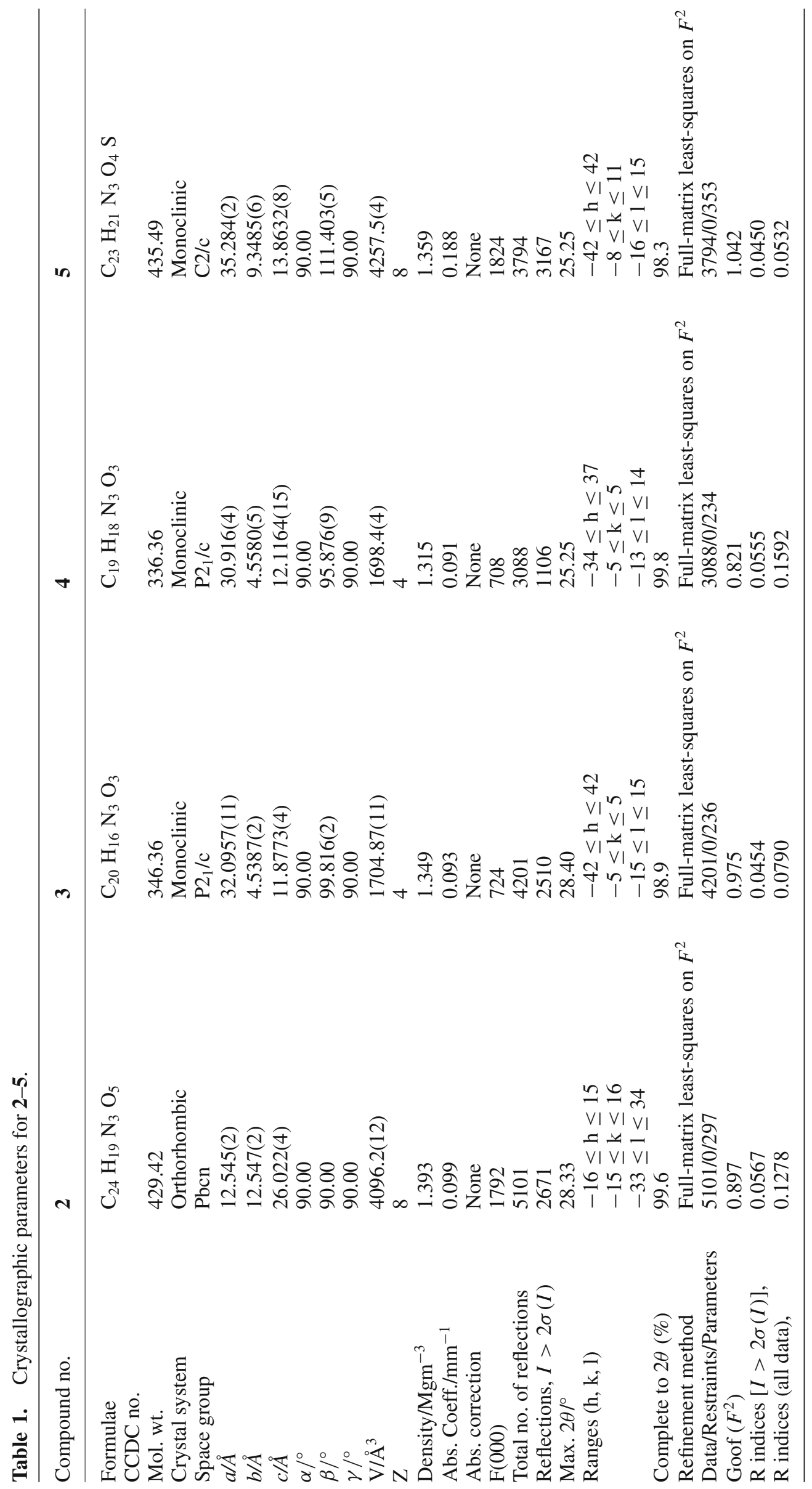


atoms were refined in the anisotropic approximation against $\mathrm{F}^{2}$ of all reflections. The $\mathrm{H}$-atoms attached to heteroatoms in these crystals were located in the difference Fourier synthesis maps, and refined with isotropic displacement coefficients. The locations of acidic protons were justified by difference Fourier synthesis map and in the refinement these were allowed for as riding atoms. The Crystallographic parameters of the salts and cocrystals are listed in table 1.

\section{Results and discussion}

Phthalic acid forms a yellow coloured salt (2) with host $\mathbf{1}$. The salt $\mathbf{2}$ crystallizes in the orthorhombic Pben space group with one protonated cation of $\mathbf{1}$ and a phthalate anion in the asymmetric unit (figure 1a). The urea tap motif is not observed in the structure of this salt, instead two hydrogen bond between the oxygen atom of the phthalate anion and the urea nitrogen atom is observed (N2-H2N… O4, N3-H3N.... O5) (table 2). Another intermolecular hydrogen bond between the protonated nitrogen atom of the quinoline ring and the carboxylate group of phthalate anion (N1-H1N...O 2 ) is also present in the crystal structure (figure 1b). The urea derivatives generally form planar urea tap motif and such motifs can be broken down by the presence of guest molecules or anions which may lead to the breakdown of the well-organized urea tap motifs. ${ }^{40}$ In this particular case there is strong intra-molecular hydrogen bond interactions in the anion makes a cyclic structure within the anion and this moiety binds to the host and it acts as acceptor for hydrogen bonding and breaks the urea taps. The role of electron withdrawing groups in retaining urea taps in lattice was studied earlier ${ }^{41}$ and it has been shown that the orientation of the aromatic groups of urea can be controlled by the urea carboxylate interactions. ${ }^{42}$

Terephthalic acid forms a colourless co-crystal (3) with host $\mathbf{1}$. The co-crystal $\mathbf{3}$ crystallizes in the monoclinic $\mathrm{P} 2{ }_{1} / \mathrm{c}$ space group where the terephthalic acid molecule lies on an inversion centre with only half of the molecule contained in the crystallographic asymmetric unit (figure 2a). The urea tap motif of the host molecule is maintained in the co-crystal (N2-H2N.... 1 , N3-H3N...O 1$)$. Another intermolecular hydrogen bonding between the quinoline $\mathrm{N}$ atom and the carboxylic acid $(\mathrm{O} 2-\mathrm{H} 2 \cdots \mathrm{N} 1)$ forms a bridge between two host molecules as shown in figure $2 \mathrm{~b}$. The hydrogen bond parameters are shown in table 3 . In this case the terephthalic acids molecules are not capable of intra-molecular hydrogen bond it does not affect the urea taps and prefers to adopt a linear arrangement.

The pair of positional isomer namely phthalic acid and terephthalic acid can also be distinguished by virtue of their colour arising from the formation of salt and co-crystal. Phthalic acids forms a yellow coloured salt whereas terephthalic acid forms a colourless co-crystal. The quinoline derivatives generally show $n-\pi *$ transition. ${ }^{43}$ Upon protonation non-bonding electrons are no longer available; energy of these levels goes beneath the $\pi$-level. This helps in generating new transition $\pi-\pi *$ transition and this transition occurs at a higher wavelength $(400 \mathrm{~nm})$ due to narrowing of energy among

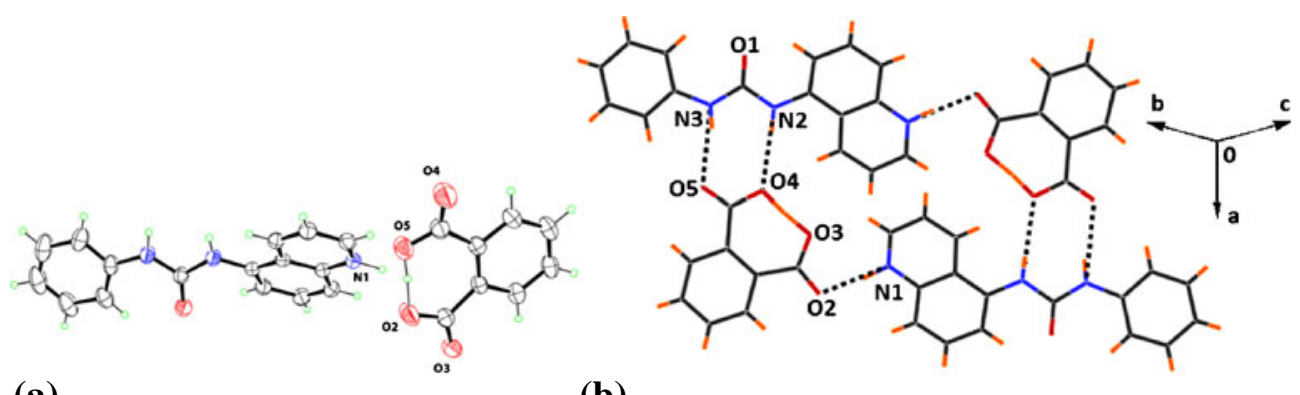

(a)

(b)

Figure 1. (a) Asymmetric unit of $\mathbf{2}$ (ORTEP diagram drawn in 50\% probability ellipsoid).

(b) Hydrogen bonding network in 2.

Table 2. Hydrogen bond distances and angles for compound 2 .

\begin{tabular}{lllll}
\hline $\mathrm{D}-\mathrm{H} \cdots \mathrm{A}$ & $d_{\mathrm{D}-\mathrm{H}}(\AA)$ & $d_{\mathrm{H} \cdots \mathrm{A}}(\AA)$ & $d_{\mathrm{D} \cdots \mathrm{A}}(\AA)$ & $<\mathrm{D}-\mathrm{H} \cdots \mathrm{A}\left({ }^{\circ}\right)$ \\
\hline $\mathrm{N}(1)-\mathrm{H}(1 \mathrm{~N}) \cdots \mathrm{O}(2)[\mathrm{x},-\mathrm{y},-1 / 2+\mathrm{z}]$ & $1.05(3)$ & $1.68(3)$ & $2.714(2)$ & $168(2)$ \\
$\mathrm{N}(2)-\mathrm{H}(2 \mathrm{~N}) \cdots \mathrm{O}(4)[-\mathrm{x}, \mathrm{y}, 1 / 2-\mathrm{z}]$ & 0.86 & 2.16 & $3.015(3)$ & 177 \\
$\mathrm{~N}(3)-\mathrm{H}(3 \mathrm{~N}) \cdots \mathrm{O}(5)[-\mathrm{x}, \mathrm{y}, 1 / 2-\mathrm{z}]$ & 0.86 & 2.14 & $2.970(3)$ & 163 \\
$\mathrm{O}(3)-\mathrm{H}(4 \mathrm{~A}) \cdots \mathrm{O}(4)$ & $1.25(4)$ & $1.12(4)$ & $2.367(3)$ & $174(4)$ \\
\hline
\end{tabular}




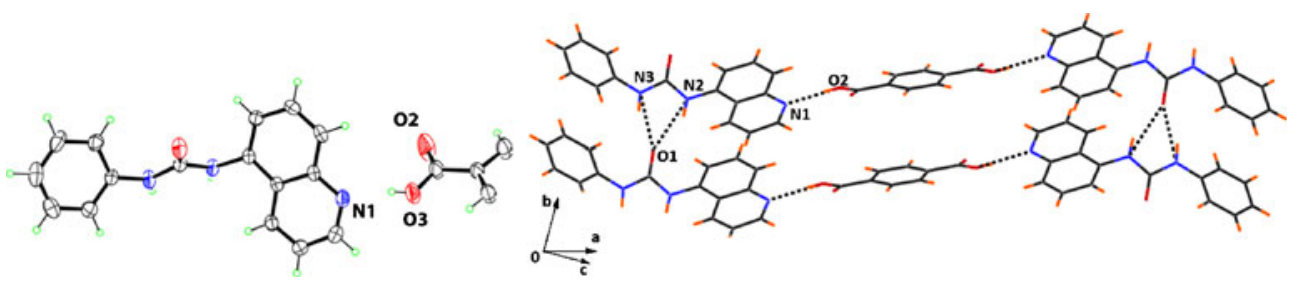

(a)

(b)

Figure 2. (a) Asymmetric unit of $\mathbf{3}$ (ORTEP diagram drawn in 50\% probability ellipsoid).

(b) Hydrogen bonding network in $\mathbf{3}$.

Table 3. Hydrogen bond distances and angles for compound $\mathbf{3}$.

\begin{tabular}{lcccc}
\hline $\mathrm{D}-\mathrm{H} \cdots \mathrm{A}$ & $d_{\mathrm{D}-\mathrm{H}}(\AA)$ & $d_{\mathrm{H} \cdots \mathrm{A}}(\AA)$ & $d_{\mathrm{D} \cdots \mathrm{A}}(\AA)$ & $<\mathrm{D}-\mathrm{H} \cdots \mathrm{A}\left({ }^{\circ}\right)$ \\
\hline $\mathrm{N}(2)-\mathrm{H}(2 \mathrm{~N}) \cdots \mathrm{O}(1)[\mathrm{x},-1+\mathrm{y}, \mathrm{z}]$ & 0.86 & 2.10 & $2.864(1)$ & 148 \\
$\mathrm{~N}(3)-\mathrm{H}(3 \mathrm{~N}) \cdots \mathrm{O}(1)[\mathrm{x},-1+\mathrm{y}, \mathrm{z}]$ & 0.86 & 1.98 & $2.779(2)$ & 155 \\
$\mathrm{O}(2)-\mathrm{H}(2 \mathrm{~A}) \cdots \mathrm{N}(1)[\mathrm{x}, 3 / 2-\mathrm{y}, 1 / 2+\mathrm{z}]$ & 0.82 & 1.89 & $2.697(2)$ & 168 \\
\hline
\end{tabular}

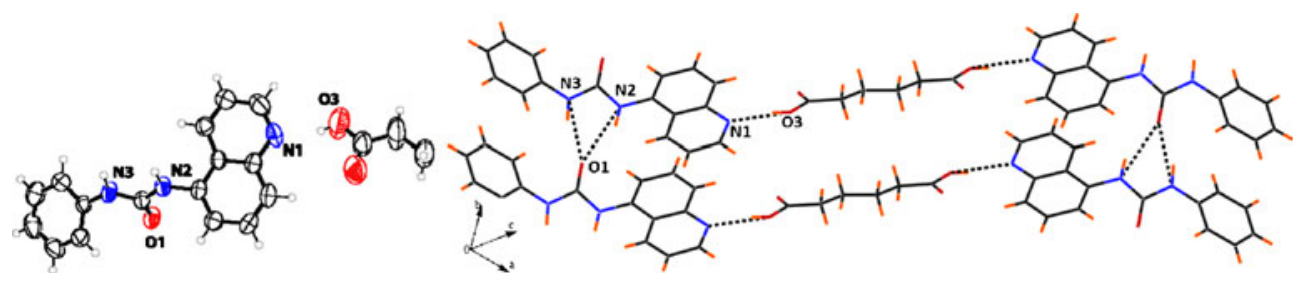

(a)

(b)

Figure 3. (a) Asymmetric unit of 4. (ORTEP diagram drawn in 50\% probability ellipsoid).

(b) Hydrogen bonding network in 4.

Table 4. Hydrogen bond distances and angles for compound 4.

\begin{tabular}{|c|c|c|c|c|}
\hline $\mathrm{D}-\mathrm{H} \cdots \mathrm{A}$ & $d_{\mathrm{D}-\mathrm{H}}(\AA)$ & $d_{\mathrm{H} \cdots \mathrm{A}}(\AA)$ & $d_{\mathrm{D} \cdots \mathrm{A}}(\AA)$ & $<\mathrm{D}-\mathrm{H} \cdots \cdot \mathrm{A}\left({ }^{\circ}\right)$ \\
\hline $\mathrm{N}(2)-\mathrm{H}(2 \mathrm{~N}) \cdots \mathrm{O}(1)[\mathrm{x},-1+\mathrm{y}, \mathrm{z}]$ & $0.85(2)$ & $2.10(2)$ & $2.870(3)$ & $150(2)$ \\
\hline $\mathrm{N}(3)-\mathrm{H}(3 \mathrm{~N}) \cdots \mathrm{O}(1)[\mathrm{x},-1+\mathrm{y}, \mathrm{z}]$ & $0.90(3)$ & $1.98(3)$ & $2.798(4)$ & $150(2)$ \\
\hline $\mathrm{O}(3)-\mathrm{H}(3 \mathrm{~A}) \cdots \mathrm{N}(1)[\mathrm{x}, 3 / 2-\mathrm{y}, 1 / 2+\mathrm{z}]$ & 0.82 & 1.92 & $2.707(5)$ & 162 \\
\hline
\end{tabular}

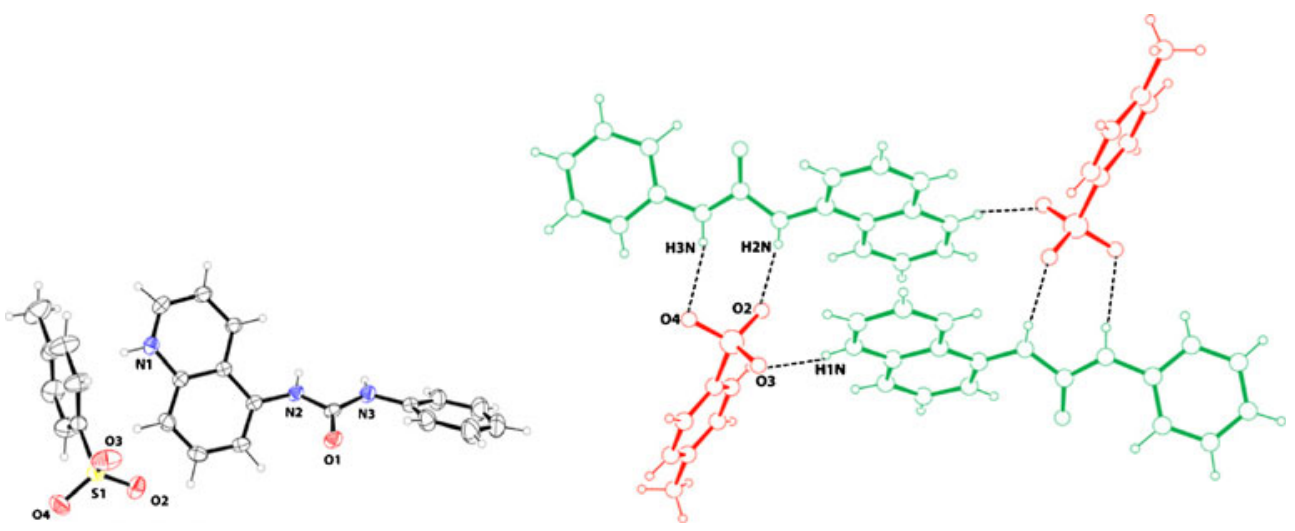

(a)

(b)

Figure 4. (a) Asymmetric unit of 5. (b) Short range interactions in $\mathbf{5}$. 
the bonding and anti bonding $\pi$-orbitals. In order to confirm that this change in absorbance is from the host part, we have also studied the UV-visible spectra of the phthalic acid and terephthalic acid. Phthalic acid absorbs at $273 \mathrm{~nm}$ and on addition of base such as triethyl amine, no absorbance in the visible region is observed. Similarly, in the case of terephthalic acid which absorbs at $285 \mathrm{~nm}$, no absorbance at the visible region is observed on addition of triethyl amine. Hence, the yellow colour of the salts is only because of the protonated form of the host $\mathbf{1}$.

The host $\mathbf{1}$ forms a colourless co-crystal with adipic acid (4). The co-crystal 4 crystallizes in the space group monoclinic $\mathrm{P} 2{ }_{1} / \mathrm{c}$ with half of the adipic acid molecule and a molecule of host $\mathbf{1}$ in the crystallographic asymmetric unit (figure 3). The co-crystal 4 forms an analogous structure with the other co-crystals by maintaining the urea tap hydrogen bonding interaction (N2H2N.... O1, N3-H3N.... 1 ) (table 4). The carboxylic acid group of adipic acid form hydrogen bonds with the quinoline $\mathrm{N}$ atom $(\mathrm{O} 3-\mathrm{H} 3 \cdots \mathrm{N} 1)$. The hydrogen bonded self-assembly of the co-crystal is shown in figure 3 .

The salt 5 crystallizes in the space group monoclinic $\mathrm{C} 2 / \mathrm{c}$ and exists as a $\mathrm{Z}^{\prime}=1$ structure with a total of two molecules in the crystallographic asymmetric unit $\left(Z^{\prime \prime}=2\right)$. The asymmetric unit consists of a $p$-tolunesulphonate anion and a protonated $\mathbf{1}$ cation. In this structure also the urea tap motif is not observed, instead the urea $\mathrm{H}$ atoms are involved in an intermolecular hydrogen bond with the $\mathrm{O}$ atom of the $p$-tolunesulphonate anion $\left(\mathrm{d}_{\mathrm{D}-\mathrm{H} \cdots \mathrm{A}}\right.$

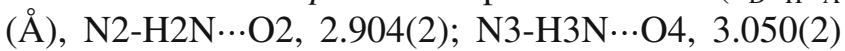
and $<\mathrm{D}-\mathrm{H} \cdots \mathrm{A}\left({ }^{\circ}\right), \quad<\mathrm{N} 2-\mathrm{H} 2 \mathrm{~N} \cdots \mathrm{O} 2,167(2)$; $<\mathrm{N} 3-$ $\mathrm{H} 3 \mathrm{~N} \cdots \mathrm{O} 4,153(1))$. Another oxygen atom O3 of the $p$ tolunesulphonate anion forms a hydrogen bond with the protonated quinoline nitrogen atom $\left(\mathrm{d}_{\mathrm{D}-\mathrm{H} \cdots \mathrm{A}}(\AA)\right.$, N1H1N...O3, 2.698(2) and <N1-H1N...O3, 156(2)). The asymmetric unit of $\mathbf{5}$ is shown in figure $4 \mathrm{a}$ along with the short range interactions in figure $4 b$.

The $p$-tolunesulphonate salt $\mathbf{5}$ shows a sharp peak at $1212 \mathrm{~cm}^{-1}$ characterestic of the $p$-tolunesulphonate anion. It may be mentioned that the type of supramolecular assembly formed by combination of carboxylic acids with pyridine depends on the difference in pKa values of each counterpart. ${ }^{31}$ But in the case of acid-base complexes with similar pKa values, the amount of proton transfer in the solid state is not a predictable parameter as a continuum exists between the two extremes. ${ }^{32}$ The terephthalic acid, phthalic acid, adipic acid and $p$-toluenesulphonic acids have pKa1 values $3.51,2.98,4.42$, and 2.8 , respectively. Thus, in the cases of the salt formation in solid and solution states by phthalic acid and $p$-toluenesulphonic acids are reasonable and follow a predictive trend.

\section{Conclusion}

The present study thus shows that the host $\mathbf{1}$ is good for distinguishing two positional isomers of dicarboxylic acid namely phthalic acid and terephthalic acid. The protonation of quinoline unit allows the system to lose the self-assembling process by two $\mathrm{N}-\mathrm{H}$ and one carbonyl oxygen of urea group of two neighbouring urea derivatives. These results also support the reasons provided on support of strong intra-molecular hydrogen bond interactions in visual distinction of maleic acid from fumeric acid by the same host. ${ }^{39}$ The terephthalic acid being an industrially important substrate for polyester fibres and plastics, contamination of phthalic acid in such material is unwanted. ${ }^{44}$ But the contaminant of terephthalic acid could be phthalic acid due to synthetic procedures, thus the presence of latter as impurity can be easily found out by using host $\mathbf{1}$ as an indicator.

\section{Supplementary materials}

The CIF data are deposited to Cambridge Crystallographic Database, CCDC Nos. are 854224-854226.

\section{References}

1. Byrne P, Turner D R, Lloyd G O, Clarke N and Steed J W 2008 Cryst. Growth Des. 83335

2. Russell J M, Parker A D M, Evans I R, Howard J A K and Steed J W 2006 Cryst. Eng. Commun. 8119

3. Amendola V, Fabbrizzi L and Mosca L 2010 Chem. Soc. Rev. 393889

4. Raposo C, Crego C, Partcarroyo A, Mussons M L, Caballero M C and Moran J R 1993 Tetrahedron Lett. 34 1995

5. Fitzmaurice R J, Kyne G M, Douheret D and Kilburn J D 2002 J. Chem. Soc. Perkin Trans. 1841

6. Shimizu T, Usui T, Machida K, Furuya K, Osadab H and Nakata T 2002 Bioorg. Med. Chem. Lett. 123363

7. Almquist R G, Chao W R and White C J 1985 J. Med. Chem. 281067

8. Bowker M J A, Stahl P H and Wermuth C G (eds) 2002 In Handbook of pharmaceutical salts (New-York: Wiley-VCH)

9. Schlesinger P H, Ferdani R, Liu J, Pajewska J, Pajewki R, Saito M, Shabany H and Gokel G W $2002 \mathrm{~J}$. Am. Chem. Soc. 1241848

10. Almaraz M, Martín M, Hernández J, Caballero M C and Morán J R 1998 Tetrahedron Lett. 391811 
11. Goodman M S, Hamilton A D and Weiss J 1995 J. Am. Chem. Soc. 1178447

12. Karle I L, Ranganathan D and Haridas V 1997 J. Am. Chem. Soc. 1192777

13. Steinke J H G, Dunkin I R and Sherrington D C 1999 Trends in analytical chemistry, 18 (Amsterdam: Elsevier)

14. Halter I P, Smith T J and Weiss J 1996 Tetrahedron Lett. 371201

15. Vicent C, Hirst S C, Garcia-Tellado F and Hamilton A D 1991 J. Am. Chem. Soc. 1135466

16. Almaraz M, Rapuso C, Martin M, Caballero C and Moran J R 1998 J. Am. Chem. Soc. 1203516

17. Hernandez J V, Almaraz M, Raposo C, Martin M, Lithgow A, Crego M, Caballero C and Moran J R 1998 Tetrahedron Lett. 397401

18. Prohens R, Rotger M C, Pina M N, Deya P M, Morey J, Ballester P and Costa A 2001 Tetrahedron Lett. 424933

19. Hosseini M W and Lehn J M 1982 J. Am. Chem. Soc. 1043525

20. Rebek Jr. J, Memeth D Ballester P, and Lin F T 1987 J. Am. Chem. Soc. 1093474

21. Trogers J 1887 J. Prakt. Chem. 36225

22. Larson S B and Wilcox C S 1986 Acta Crystalogr. C42 224

23. Wilcox C S, Adrian J C, Webb T H and Zawacki F J 1992 J. Am. Chem. Soc. 11410189

24. Goswami S, Ghosh K and Dasgupta S 2000 J. Org. Chem. 651907

25. Goswami S and Ghosh K 1997 Tetrahedron Lett. 38 4503

26. Zheng Y-S and Zhang C 2004 Org. Lett. 61189

27. Mohamed S, Tocher D A, Vickers M, Karamertzanis P G and Price S L 2009 Cryst. Growth Des. 92881
28. Singh W M, Barooah N and Baruah J B $2008 \mathrm{~J}$. Mol. Struct. 875329

29. Haynes D A, Jones W and Motherwell W D S 2006 Cryst. Eng. Commun. 8830

30. Stanton M K and Bak A 2008 Cryst. Growth Des. 8 3856

31. Bhogala B R, Basavoju S and Nangia A 2005 Cryst. Eng. Commun. 7551

32. Childs S L, Stahly G P and Park A 2007 Mol. Pharmaceut. 4323

33. Sarma B, Nath N K, Bhogala B R and Nangia A 2009 Cryst. Growth Des. 91546

34. Kishikawa K, Iwashima C, Kohmoto S, Yamaguchi K and Yamamoto M 2000 J. Chem. Soc. Perkin. Trans. I 2217

35. Lavin J M and Shimizu K D 2006 Org. Lett. 8 2389

36. Steiner T 2002 Angew. Chem. Int. Ed. Eng. 4748

37. Shan N, Batchelor E and Jones W 2002 Tetrahedron Lett. 438721

38. Vishweshwar P, Nangia A and Lynch V M 2003 Cryst. Growth Des. 3783

39. Kalita D, Baruah J B 2010 J. Mol. Struct. 96975

40. Todd A M, Anderson K M, Byrne P, Goeta A E and Steed J W 2006 Cryst. Growth Des. 61750

41. Reddy L S, Basavoju S, Vangala V R and Nangia A 2006 Cryst. Growth Des. 6161

42. Zafar A, Geib S J, Hamuro Y and Hamilton A D 1998 New J. Chem. 22137

43. de Silva A P, Gunaratne H Q N, Gunnlaugsson T, Huxley A J M, McCoy C P, Rademacher J T and Rice T E 1997 Chem. Rev. 971515

44. Che Y-K, Qu Y-X and Wang S 2009 J. Chem. Eng. Data 543130 